\title{
EFFECTS OF HYSTERECTOMY ON CORPUS LUTEUM ACTIVITY IN THE CYCLIC, PSEUDOPREGNANT AND PREGNANT MOUSE
}

\author{
A. D. DEWAR \\ Department of Physiology, University Medical School, \\ Teviot Place, Edinburgh EH8 $9 A G$
}

(Received 17th February 1972)

\begin{abstract}
Summary. No significant effects on the duration of subsequent oestrous cycles, the duration of pseudopregnancy or on the other characteristics of pseudopregnancy were observed after hysterectomy in albino mice. In pregnancy, except for a slight transient effect on Day 10 , the residual duration of luteal activity (as measured by the duration of the extrauterine weight loss and the interval to oestrus) was independent of the presence or absence of the uterus and pregnancy was maintained by a single contralateral ovary associated with an isolated non-pregnant horn.

Loss of the placentae by hysterectomy or uterine evacuation on the 8th day of pregnancy had no influence on the duration of CL activity when compared with that of pseudopregnant animals. Thereafter, the duration of residual luteal activity declined to a near constant level from the 14th day onwards and this decline was accompanied by a reduction in the variability of the life of the CL normally seen in pseudopregnancy. Placental removal after the 14th day was followed by almost immediate cessation of luteal function which at no time (with the possible exception of the 18th day) continued for the remainder of the gestation period.
\end{abstract}

\section{INTRODUCTION}

Pregnancy in the mouse is terminated by the removal of the ovaries or destruction of the CL unless these are replaced by exogenous progesterone (Parkes, 1928; Robson, 1938a, b; Steinetz, Beach \& Kroc, 1956; Hall, 1957). Removal of the pituitary after the 11 th day, however, does not result in termination of pregnancy (Selye, Collip \& Thomson, 1933; Newton \& Beck, 1939; Gardner \& Allen, 1942; Choudary \& Greenwald, 1969). The existence in the pregnant mouse of a source of ovarian stimulation other than the pituitary was first shown by Mirskaia (1930) and was later established by Newton and his colleagues (see Newton, 1949) who demonstrated an ovary-placenta relationship in the maintenance of the maternal characteristics of pregnancy. Confirmatory evidence of luteotrophic activity of the placenta (or trophoblast) has subsequently arisen (Cerruti \& Lyons, 1960; Kirby, 1965; Zeilmaker, 1968). 
Interruption of the ovary-placenta relationship by emptying the uterus (Newton, 1935; Deanesly \& Newton, 1940) or by hysterectomy (Dewar, 1957a) results in involution of the CL and a reversal of the maternal pregnancy changes readily observable in the loss of the extrauterine body weight gain and a return to oestrus in a few days. Newton (1935) noted that the interval between uterine evacuation and oestrus in a few animals was somewhat longer when the operation was performed on the 12th as compared with the 18th day of pregnancy, but no reinvestigation of this observation has since been made. Although the earlier work has clearly established the dependence of the CL on placental endocrine function, the degree of this dependence may be questioned in the light of more recent observations on the duration of pseudopregnancy which, in some mice, can be as long as the normal gestation period (Dewar, 1959). The rôle of the uterus itself in the control of the CL of pregnancy requires further investigation although the indications are (Dewar, 1957a; McLaren, 1970) that it plays no significant part.

The work described here compares the effects of total hysterectomy with those of placental removal with all or part of the uterus remaining, on the rate of extrauterine weight loss and the delay before oestrus as indicators of diminishing luteal function. The influence of hysterectomy on subsequent ovarian cycles and on the duration of pseudopregnancy has also been investigated. Despite the great attention in recent years to the luteolytic action of the uterus in many species (see Bradbury, Brown \& Gray, 1950; Perry \& Rowlands, 1961; Anderson, Bowerman \& Melampy, 1963; Rothchild, 1965; Melampy \& Anderson, 1968; Anderson, Bland \& Melampy, 1969), the mouse appears to have been neglected in this context, although the species has sometimes been unwarrantably linked with the rat (e.g. Nalbandov, 1961). The earliest descriptions of the effects of hysterectomy in the mouse appear to be those of Westman (1929) who found no effect of prepubertal hysterectomy on ovarian structure or vaginal cytology, of Bradbury (1932) who was concerned only with the consequences to mammary activity, and of Palmer \& Fulton (1941) who investigated the effect of hysterectomy on threshold doses of chorionic gonadotrophin.

\section{MATERIALS AND METHODS}

\section{Animals and operative procedures}

The mice were derived from a closed colony of randomly interbred albinos. They were kept in a constant-temperature room $\left(21^{\circ} \mathrm{C}\right)$, fed mouse cake of constant composition and given water. All operations were performed aseptically under sodium amytal anaesthesia through a mid-line abdominal incision. The whole uterus, or one horn only, was excised just above the cervix and at the uterotubal junction after ligaturing each of these points, together with the uterine blood vessels. Isolation of one horn was carried out in non-pregnant animals by ligaturing the horn as near to the cervix as possible and sectioning the horn above the ligature while leaving the main arcuate blood vessels intact. Uterine evacuation was performed by removing each conceptus in turn through a small adjacent incision in the antimesometrial border of the uterus. 


\section{Pseudopregnancy experiments}

Pseudopregnancy was induced by mating with vasectomized males and was dated from the finding of the vaginal plug. The mice were weighed twice daily and vaginal smears were examined daily. Pseudopregnancy was defined as the period of anoestrus following mating, accompanied by a persistent mucified smear and a gain in body weight which was lost on returning to oestrus (Dewar, 1957b). The duration of pseudopregnancy was taken as the interval between the day of mating and the first subsequent oestrous smear (nucleated squamous epithelial cells).

Pseudopregnancies were examined in a total of forty-two hysterectomized and sixty intact mice belonging to two main groups. Group 1 consisted of forty-two virgin mice of 5 to 6 months of age at the beginning of pseudopregnancy; eighteen of these were hysterectomized 2 to 3 weeks before the induction of pseudopregnancy and the remaining twenty-four were used as intact controls over the same period of examination. Group 2 were all parous animals from an earlier experiment; their parity varied from one to five previous pregnancies and their ages from 8 to 12 months; this group consisted of thirty-six intact females and twenty-four mice hysterectomized 2 to 3 weeks before mating with vasectomized males; pseudopregnancies in both intact and hysterectomized mice were examined over the same period and under the same conditions. Examination of vaginal smears was continued after the cessation of pseudopregnancy for about four cycles in each of fifteen hysterectomized and seventeen intact mice of Group 1 and the durations of the cycles were compared. The length of each cycle was timed from the first pro-oestrous smear to the day before the subsequent similar smear.

\section{Pregnancy experiments}

Pregnant mice of 5 to 7 months of age were used. The pregnancies were timed from the finding of a vaginal plug, the midnight of this day being taken as the end of the first day of gestation. Placental removal was effected, with or without removal of the uterus, in one of the following ways (a) total hysterectomy, (b) evacuation of the uterus, or (c) hemihysterectomy, i.e. by removal of the pregnant horn of a unilateral pregnancy occurring spontaneously or achieved by an earlier operation involving either ligaturing the Fallopian tube on one side or by isolating one horn at the cervical end. One of these methods was applied to each of a total of 145 mice at different stages of pregnancy from the 8 th to 18 th days. After the operation, daily vaginal smears were taken and the mice were weighed each morning and late afternoon. Comparisons of the loss of the progesterone-controlled extrauterine weight gain of pregnancy were made in terms of the time taken for the loss of $90 \%$ of the total weight loss, the latter being arbitrarily defined as the difference between the weight immediately after operation and that on the day after the first vaginal oestrus.

\section{RESULTS}

Influence of hysterectomy on the oestrous cycle

The duration of the cycles of fifteen hysterectomized and seventeen intact 
mice of the same age were compared; a total of sixty-three cycles was observed in each group. The mean duration in the intact group was 5.52 days \pm 1.01 (S.D.) and in the hysterectomized group 5.47 days \pm 1.06 (S.D.). The absence of the uterus, therefore, had no apparent influence on the CL of the oestrous cycle.

\section{Influence of hysterectomy on the duration of pseudopregnancy}

The mean duration of pseudopregnancy in all of the forty-two hysterectomized mice studied (Groups 1 and 2 combined) was 19.8 days \pm 5.3 (S.D.) which was not significantly different $(P>0.05)$ from the sixty intact mice of these two groups, the mean value for which was $18 \cdot 1$ days $\pm 4 \cdot 0$ (S.D.).

The results for the virgin mice (Group 1 ) are given in Table 1 and Text-fig. 1. Although the mean figure for the duration of pseudopregnancy in the hysterectomized group was approximately 2 days longer than that of the intact mice,

Table 1. Comparison of pseudopregnancies in intact and hysterectomized virgin mice of same age (Group 1)

\begin{tabular}{l|c|c|c|c|c}
\hline Description & $\begin{array}{c}\text { No. of } \\
\text { mice }\end{array}$ & $\begin{array}{c}\text { Mean duration } \\
\pm S . D .(\text { days })\end{array}$ & $\begin{array}{c}\text { Mean maximum } \\
\text { weight increase } \\
(\%)\end{array}$ & $\begin{array}{c}\text { Mean day } \\
\text { of maximum } \\
\text { weight increase }\end{array}$ & $\begin{array}{c}\text { Mean day of } \\
\text { first mucous } \\
\text { smear }\end{array}$ \\
\hline Intact & 24 & $\begin{array}{c}17.7 \pm 5.0 \\
(12 \text { to } 33)\end{array}$ & $7 \cdot 2 \pm 2 \cdot 5$ & $11 \cdot 5 \pm 4 \cdot 1$ & $4 \cdot 3 \pm 1.0$ \\
Hysterectomized & 18 & $\begin{array}{c}19.7 \pm 4.8 \\
(13 \text { to } 29) \\
P 0.1\end{array}$ & $7 \cdot 2 \pm 3.3$ & $14.3 \pm 4.8$ & $4 \cdot 7 \pm 1.4$ \\
$P$ & & $>0.1$ & $>0.1$ & $>0.1$ \\
\hline
\end{tabular}

Range in days is given in parentheses.

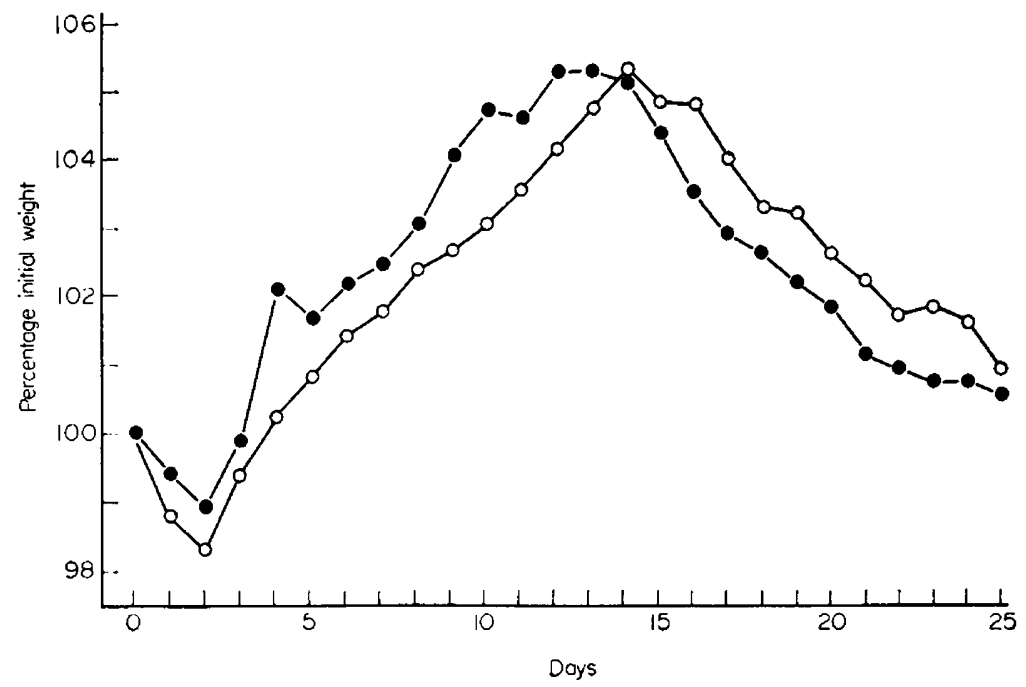

TExT-Fig. 1. Average weight changes during pseudopregnancy in intact $(\bullet)$ and hysterectomized $(0)$ virgin mice, expressed as percentage of weight at time of mating (Day 0 ) with vasectomized males. 
the difference was not statistically significant $(P>0 \cdot 1)$. No significant differences were apparent either in the secondary measurements of body-weight increase, day of maximum weight increase or day on which a mucified vaginal smear was first observed.

Again, in the parous group (Group 2), the length of pseudopregnancy in the hysterectomized mice was not significantly longer, whether all the mice were grouped or subdivided according to age (Table 2). On the other hand, there was a statistically significant increase in the duration of pseudopregnancy in the older animals, intact and hysterectomized. It appears, therefore, that, whereas hysterectomy is without effect, either age or parity, or both, may influence pseudopregnancy duration.

\section{Influence of placental removal at different stages of pregnancy on corpus luteum activity}

The delay between removal of the placentae by hysterectomy or other means and the onset of oestrus and the rate of loss of body weight were taken as indices

Table 2. Comparison of duration of pseudopregnancy in intact and hysterectomized mice of different ages and parity (Group 2)

\begin{tabular}{|c|c|c|c|c|c|c|c|}
\hline \multirow[b]{2}{*}{$\begin{array}{c}\text { Age } \\
\text { (months) }\end{array}$} & \multicolumn{3}{|c|}{ Intact } & \multicolumn{3}{|c|}{ Hysterectomized } & \multirow[b]{2}{*}{$\mathrm{P}$} \\
\hline & $\begin{array}{c}\text { No. of } \\
\text { mice }\end{array}$ & $\begin{array}{l}\text { Mean } \\
\text { parity }\end{array}$ & $\begin{array}{l}\text { Mean duration } \\
\pm S . D . \\
\quad(\text { days })\end{array}$ & $\begin{array}{c}\text { No. of } \\
\text { mice }\end{array}$ & $\begin{array}{l}\text { Mean } \\
\text { parity }\end{array}$ & $\begin{array}{c}\text { Mean duration } \\
\pm \text { S.D. } \\
\quad \text { days })\end{array}$ & \\
\hline All ages & 36 & 1.4 & $\begin{array}{l}18 \cdot 3 \pm 3 \cdot 2 \\
(14 \text { to } 27)\end{array}$ & 24 & 1.9 & $\begin{array}{l}19 \cdot 9 \pm 5 \cdot 7 \\
(12 \text { to } 36)\end{array}$ & $>0 \cdot 1$ \\
\hline 7 to 9 & 19 & 1.0 & $\begin{array}{l}17 \cdot 1 \pm 2 \cdot 7 \\
(14 \text { to } 24)\end{array}$ & 9 & $1 \cdot 0$ & $\begin{array}{l}17 \cdot 6 \pm 2 \cdot 1 \\
(13 \text { to } 21)\end{array}$ & $>0 \cdot 1$ \\
\hline 10 & 5 & 1.8 & $\begin{array}{l}19 \cdot 0 \pm 3 \cdot 1 \\
(15 \text { to } 22)\end{array}$ & 8 & 1.9 & $\begin{array}{l}20 \cdot 3 \pm 7 \cdot 3 \\
(12 \text { to } 36)\end{array}$ & $>0.1$ \\
\hline 11 to 12 & 12 & $1 \cdot 8$ & $\begin{array}{l}19 \cdot 8 \pm 3 \cdot 4 \\
(16 \text { to } 27)\end{array}$ & 7 & $3 \cdot 1$ & $\begin{array}{l}22 \cdot 6 \pm 6 \cdot 1 \\
(17 \text { to } 34)\end{array}$ & $>0.1$ \\
\hline$P^{*}$ & \multicolumn{3}{|c|}{$=0.02$} & \multicolumn{3}{|c|}{$<0.05$} & \\
\hline
\end{tabular}

Range in days is given in parentheses.

* Comparison of youngest and oldest groups.

of the continued duration of progesterone, and therefore of ovarian, activity. The results of such treatment on the 8th to the 18th day of pregnancy are given in Table 3 and Text-fig. 2. The values for the two measurements are closely related. The interval between placental removal and the onset of oestrus declined significantly $(P<0.001)$ from 6.9 days on the 8 th day to 3.1 on the 14th and thereafter remained at a near constant level of about 3 days. Similar results were given for the rate of weight loss.

Experiments on non-pregnant mice of the same stock with progesterone tablet implants for periods of from 20 to 47 days have shown that oestrus returns on the 2 nd or 3 rd day after removal of the tablets (mean of twenty cases was 2.6 days \pm 0.3 S.D.). Since the latency before oestrus was only slightly, but significantly $(P<0.02)$, longer than 2.6 days after placental removal on Days 14 and 15, and indistinguishable $(P>0 \cdot 1)$ on Days 17 and 18, it appears 


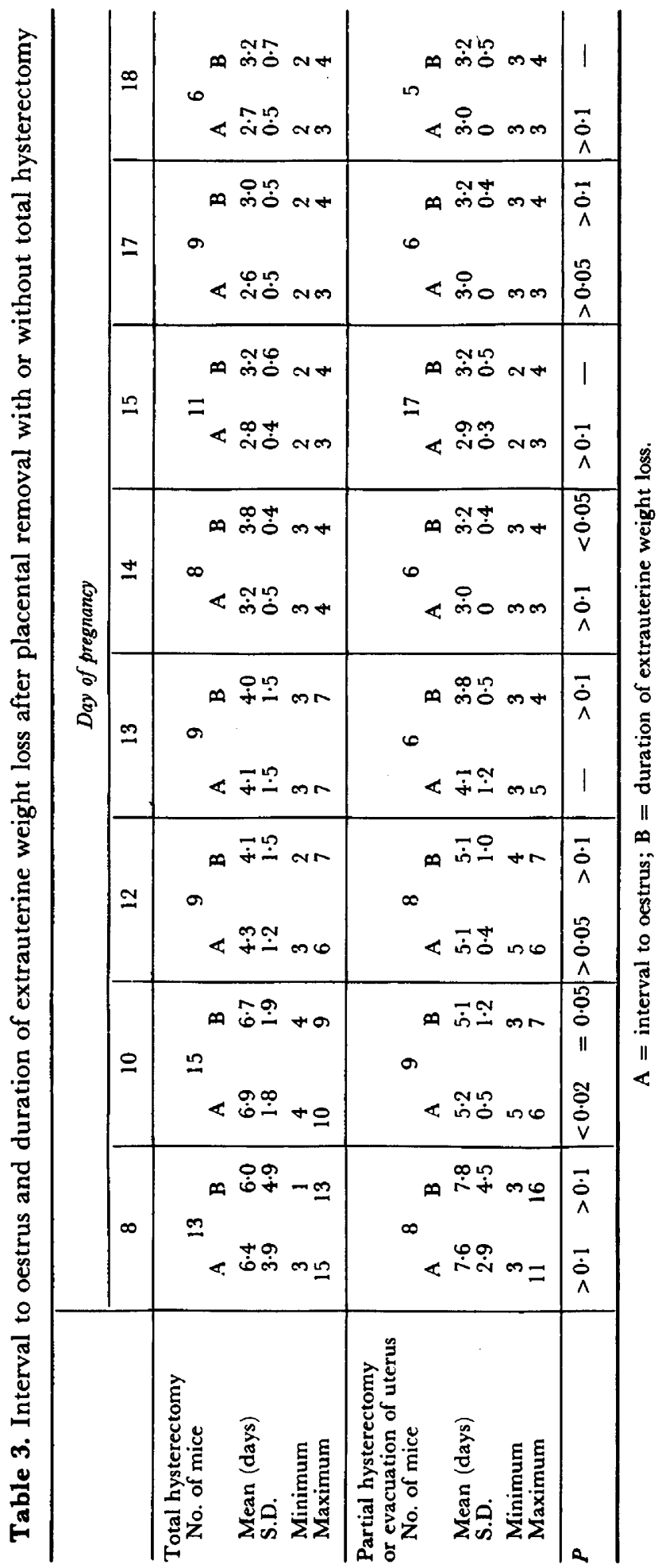




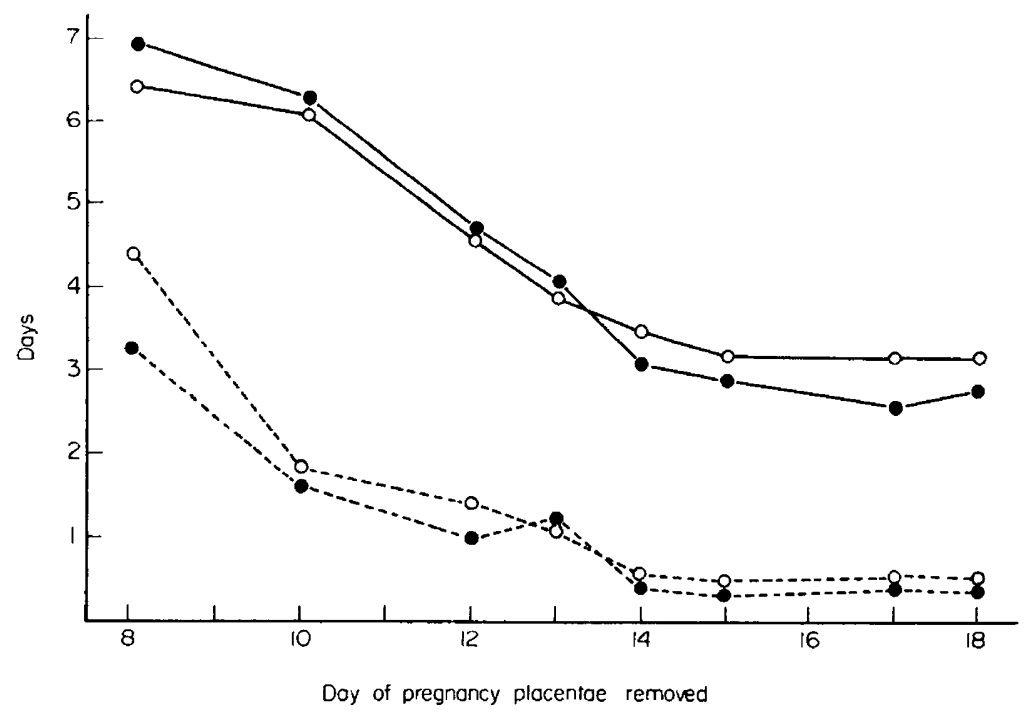

Text-fig. 2. Above: interval between removal of placentae at different stages of pregnancy and onset of oestrus ( ) and duration of extrauterine weight loss $(0)$. Below: corresponding standard deviations, indicating decline in variability in duration of $\mathrm{CL}$ activity in last half of pregnancy.

that cessation of corpus luteum activity following loss of the placentae is almost immediate at these times. At no stage in pregnancy, with the possible exception of Day 18, did ovarian activity continue for the remainder of the gestation period after the placentae were removed. In normal pregnancies, oestrus occurred approximately 1 day after parturition $(0.9$ day $\pm 0.3 \mathrm{~S} . \mathrm{D}$. in forty-five cases), i.e. on the 21 st day after detection of a vaginal plug in the majority of mice.

It can be inferred from the results of hypophysectomy in pregnant mice (see references above) that pituitary stimulation of the ovary is essential until about the 11 th day. In the present work, placental removal on the 8th day was without effect upon the duration of the CL when compared with that in a group of pseudopregnant mice subjected to sham-operation on the 8th day after sterile mating (mean interval to oestrus for six mice was 8.0 days \pm 3.9 S.D., $P>0.1$ ), confirming that, at this stage, the pituitary is the controlling factor. The decreasing delay between removal of the placentae and oestrus at later stages of pregnancy (Text-fig. 2) probably represents the declining influence of pituitary luteotrophic activity. This is indicated also in the reduction from the 8th day onwards of the variability of this parameter (as shown by the increasing reduction in the standard deviation-see Table 3 and Text-fig. 2); in this strain of mice, the duration of activity of the CL of pseudopregnancy is very variable (Dewar, 1959 and Tables 1 and 2), the range extending from 9 to 36 days, and a considerable proportion of the animals having pseudopregnancies as long as, or longer than, the gestation period $(27 \%$ of 193 pseudopregnancies examined lasted 19 days or over). The abolition of this variability in CL activity in pregnancy suggests that the luteotrophic influence of the pituitary which 
initiates such activity not only becomes redundant in later pregnancy but is suppressed (after about the 13th day).

\section{Influence of the uterus on the corpora lutea of pregnancy}

Comparison of duration of luteal activity after placental removal with or without the uterus. In the above experiments, placental removal was effected either by total hysterectomy or by one of several methods which left the whole uterus, or one horn, in place. In the Day-15 group, the mice of the latter treatment were composed of (a) mice in which the conceptuses were separately removed leaving both horns intact, (b) those in which the gravid horn only was removed, unilateral pregnancy having been achieved by previously tying off one Fallopian tube, and (c) those in which the gravid horn only was removed in unilateral pregnancies achieved by the earlier separation of one horn near the cervix. Method (c) was employed to obviate any interference by the tube-tying operation with hypothetical local pathways to the ovary for 'uterine luteolysin' and also to eliminate the possibility of any 'antiluteolytic' factor from the pregnant horn gaining access to the sterile side (see Moor \& Rowson, 1966).

Table 4. Interval before onset of oestrus and duration of extrauterine weight loss after placental removal on 15th day of pregnancy by total or partial hysterectomy or uterine evacuation

\begin{tabular}{|c|c|c|c|c|c|}
\hline & \multirow{2}{*}{$\begin{array}{c}\text { No. of } \\
\text { mice }\end{array}$} & \multicolumn{2}{|c|}{ Interval before oestrus (days) } & \multicolumn{2}{|c|}{ Duration weight loss (days) } \\
\hline & & Mean \pm S.D. & $\mathbf{P}$ & Mean $\pm S . D$. & $\mathbf{P}$ \\
\hline Total hysterectomy & 11 & $\begin{array}{l}2 \cdot 8 \pm 0 \cdot 8 \\
(2 \text { to } 3)\end{array}$ & - & $\begin{array}{l}3 \cdot 2 \pm 0 \cdot 6 \\
(2 \text { to } 4)\end{array}$ & - \\
\hline Uterine evacuation & 6 & $\begin{array}{l}2 \cdot 8 \pm 0 \cdot 4 \\
(2 \text { to } 3)\end{array}$ & $>0 \cdot 1$ & $\begin{array}{l}3 \cdot 0 \pm 0 \cdot 6 \\
(2 \text { to } 4)\end{array}$ & $>0 \cdot 1$ \\
\hline Removal one horn only $A^{*}$ & 7 & $\begin{array}{c}3 \cdot 0 \pm 0 \cdot 0 \\
(-)\end{array}$ & $>0.1$ & $\begin{array}{l}3.4 \pm 0.5 \\
(3 \text { to } 4)\end{array}$ & $>0 \cdot 1$ \\
\hline Removal one horn only $\mathrm{B} \dagger$ & 4 & $\begin{array}{c}3 \cdot 0 \pm 0 \cdot 0 \\
(-)\end{array}$ & $>0 \cdot 1$ & $\begin{array}{c}3 \cdot 0 \pm 0 \cdot 0 \\
(-)\end{array}$ & $>0 \cdot 1$ \\
\hline
\end{tabular}

Range in days is given in parentheses.

* A-unilateral pregnancy occurring naturally or achieved by tying Fallopian tube on one side. $\uparrow \mathrm{B}$ - unilateral pregnancy achieved after isolating one horn at cervical end.

The results for Day 15 are given in Table 4. No difference was shown either in the interval before oestrus or in the rate of weight loss after placental removal between the totally hysterectomized mice and those with the uterus remaining after the various procedures described.

Comparisons between totally hysterectomized mice and those with one horn or the whole uterus left on each of the other days of pregnancy examined are shown in Table 3. Only on Day 10 was there a slight indication of a lengthening of the period of residual activity of the CL in the totally hysterectomized group. The estimated maximum functional life of the CL (i.e. duration from mating to oestrus less 2 days) in all eighty totally hysterectomized mice was 15.2 days \pm 2.7 S.D. as compared with $15 \cdot 4$ days $\pm 2 \cdot 0$ S.D. for the sixty-five mice with all or part of the uterus remaining $(P>0 \cdot 1)$. 
Maintenance of pregnancy by ovary adjacent to a non-gravid horn. Nine mice whose right uterine horn had been 'isolated' by separation near the cervix were mated with intact males and the left ovary was removed on the 10th day of pregnancy. Seven of these mice were killed on the 16th or 17th day. All contained viable fetuses in the left horn; the weights of the fetuses (mean $0.44 \mathrm{~g}$ for four mice on 16 th day and $0.5 \mathrm{~g}$ for three mice on 17 th day) were within the range for fetuses of normal pregnancies at these times (mean $0.4 \mathrm{~g}$ and $0.59 \mathrm{~g}$, respectively). Two animals were allowed to go to term and gave birth to living litters of six and three young on the 20th and 21 st day, respectively. Since the ipsilateral ovary was able to maintain pregnancy, there is no indication from this experiment of any luteolytic action of the non-pregnant horn even though isolated from direct connection with the pregnant side. The experiment also demonstrates that the influence of the placentae on the ovary is systemic, rather than local.

\section{DISCUSSION}

Effects of hysterectomy on the corpora lutea of the oestrous cycle and pseudopregnancy

A related species, the rat, is classified by Rothchild (1965) as one in which the luteolytic action of the uterus is moderate. In this species, while the relatively inactive cyclic $\mathrm{CL}$ are unaffected by hysterectomy, removal of the uterus prolongs the life of the active CL of pseudopregnancy by 4 to 6 days (Long \& Evans, 1922; Murphy, 1934; Bradbury, 1937; Hechter, Fraenkel, Lev \& Soskin, 1940; Bradbury, Brown \& Gray, 1950; Tutze, 1952; Perry \& Rowlands, 1961). To the extent that hysterectomy is without effect upon the oestrous cycle of the mouse, the present findings are in agreement with those in the rat. Considering the apparent similarity of reproductive patterns in these species, it is of interest that the mouse uterus, unlike that of the rat, exerts no obvious luteolytic influence on the CL of pseudopregnancy. The absence of an effect of hysterectomy on pseudopregnancy in the mouse is in accord with the negative findings of a luteolytic action of the uterus in pregnancy in this species (Dewar, 1957a; McLaren, 1970). Of possible pertinence also is the observation of Duby, McDaniel, Spilman \& Black (1969) that, whereas rat uterine tissue transplanted into hysterectomized hamsters reduced the length of pseudopregnancy in the recipient, mouse uterine transplants were ineffective. It appears, therefore, that the mouse can be added to the phylogenetically unrelated group in which the uterus does not influence function in this way (Rothchild, 1965).

Attention has been drawn previously to the variability in the length of pseudopregnancies of normal intact mice (Dewar, 1959), a phenomenon which is not unknown in the rat. Long \& Evans (1922), for instance, observed pseudopregnancies in rats ranging from 8 to 25 days, Slonaker (1929) from 7 to 19 days, and Silbiger \& Rothchild (1963) from 10 to 19 days. Such variability appears to argue against interpreting the luteolytic action of the uterus in rats as a mechanism evolved for the curtailment of the effects of sterile matings (pseudopregnancies). The wide range of duration of apparently normal pseudopregnancies (i.e. the prolonged dioestrus occasioned by sterile mating and accompanied by the characteristic weight changes) in mice continues after hysterectomy. The causes of such variability may be numerous. Since individual 
mice can show considerable length variations in successive pseudopregnancies, genetic variation does not appear to be a primary factor. The present work indicates that age and possibly parity may be involved. Following the work of Whytten, Bruce and others (see Bruce, 1967) on the effects of olfactory stimuli on cyclic events and pregnancy in mice, it seems probable that the conditions governing the duration of pseudopregnancy, which is ultimately dependent upon pituitary gonadotrophin secretion, may also be influenced by environmental and social factors.

\section{Effects of placental removal and hysterectomy on the corpora lutea of pregnancy}

The interval between removal of the placentae and the onset of oestrus and the rate of loss of the extrauterine weight gained during pregnancy are indications of residual progesterone activity. In the absence of the placentae, such criteria are a measure of the continued activity of the CL (or other progesteronesecreting ovarian tissue).

The results can be interpreted in terms of (a) residual activity of the ovary after the removal of placental luteotrophic stimulation, (b) continued ovarian activity due to pituitary luteotrophic stimulation, and (c) immediate loss of a possible source of progesterone in the placentae themselves. Forbes \& Hooker (1957) have suggested that the second peak that they observed in plasma progestin levels at about the 15 th day is due to placental progestin. Since, however, the ovaries are required throughout pregnancy in this species, it appears probable that the ovaries are still producing progesterone at this and subsequent times.

The effects of complete progesterone withdrawal become evident in the onset of oestrus within 2 or 3 days and, since this period is not exceeded after placental removal on the 17th or 18th day, it indicates that cessation of ovarian activity is immediate at these times. On Days 14 and 15, a slight residual ovarian activity continues which can be interpreted as due either to a more powerful prior luteotrophic stimulus (probably entirely placental at this time), or to a greater responsiveness of the ovaries. On Day 8, placental removal has no effect on the CL, the activity of which continues as in pseudopregnancy; thereafter, from Days 10 to 14, the declining interval between the operation and oestrus may be explained as due primarily to reduction in pituitary luteotrophic activity; this period corresponds to a time of increased gonadotrophin content of the pituitary according to Ladman \& Runner (1953). That suppression of luteotrophin production by the pituitary is occurring at this time in a more precise manner than that occurring in pseudopregnancy is suggested by the increasing reduction in the variability of the duration of luteal activity which is a feature of pseudopregnancy in this strain of mice. From the 12th to 15th days, out of seventy-four animals, two only came into oestrus after the 18th day, whereas it is to be expected that approximately eighteen would have done so had the pituitary luteotrophic mechanism of pseudopregnancy remained in operation. The more effective negative feed-back evidently operating in pregnancy may be due to higher steroid levels occasioned by the establishment at about the 10th day of an effective ovarian stimulation by the placentae.

The result of the pituitary luteotrophin suppression is that the CL become 
entirely dependent upon the placental stimulus in later pregnancy. At no time in pregnancy (except possibly the 18th day or after) following removal of the placentae, are the CL able to continue functioning for the remainder of the gestation period.

For most of pregnancy, there is no indication from this work that the presence of the uterus or of one uterine horn, even when sterile and isolated from the pregnant horn, exerts a local or systemic luteolytic effect in hastening the functional decline of the CL after removal of the placentae. There is an apparently significant $(P<0.02)$ exception to this on Day 10 in the measurement of the delay before oestrus only. This is curious in view of the absence of any significant effect on Day 8 or on subsequent days and of any uterine luteolytic effect in pseudopregnancy. It is possibly attributable to an influence on the pituitary of the operative procedure itself on an innervated uterus occurring at a critical phase ('transitional stage' described by Choudary \& Greenwald, 1969) of declining pituitary and increasing placental luteotrophic dominance.

The absence of a luteolytic effect in pregnant mice is shown also in the ability to maintain a unilateral pregnancy by a single contralateral ovary associated with a non-pregnant horn. This was previously demonstrated by McLaren (1970) who showed that eggs survived when transplanted into one horn even though the ipsilateral ovary was removed at the time of transplanting. The conclusion concerning the absence of a luteolytic effect of the nonpregnant horn is strengthened by the present experiment in which the nonpregnant horn was isolated to eliminate the possibility of a humoral antiluteolytic influence from the pregnant side similar to that which occurs in the ewe (Moor \& Rowson, 1966). The experiment indicates also that the placental influence on ovarian activity is entirely or predominantly systemic.

This systemic luteotrophic action of the placentae might override any luteolytic effect of the mouse uterus, as has been suggested for the rat (Strauss \& Lindner, 1969) and the guinea-pig (Deanesly, 1967). However, the experiments described above which demonstrate that the uterus has no effect on the life of the CL after placental removal make such an explanation unnecessary in mice. In rats, hysterectomy from the 4 th to the 16 th day of pregnancy is reported to cause persistence of the life of the CL for a period approximating to the gestation period (Bradbury, 1937; Hechter, Fraenkel, Lev \& Soskin, 1940), although the experiments of Klein (1935) and of Waynforth (197I) apparently contradict these findings.

In another respect related to uterine influences, the rat differs from the mouse. Ershoff \& Deuel (1943) demonstrated that the induction of deciduomata in rats prolonged pseudopregnancy, whereas Kamell \& Atkinson (1948) found no such effect in mice.

\section{ACKNOWLEDGMENT}

This investigation was, in part, supported by a research grant from the Medical Research Council.

Anderson, L. L., Bland, K. P. \& Melampy, R. M. (1969) Comparative aspects of uterinc-luteal relationships. Recent Prog. Horm. Res. 25, 57. 
Anderson, L. L., Bowerman, A. M. \& Melampy, R. M. (1963) Neuro-utero-ovarian relationships. In: Advances in Neuroendocrinology, p. 343. Ed. A. V. Nalbandov. University of Illinois Press, Urbana.

Bradbury, J. T. (1932) Study of endocrine factors influencing mammary development and secretion in the mouse. Proc. Soc. exp. Biol. Med. 30, 212.

Bradbury, J. T. (1937) Prolongation of the life of the corpora lutea by hysterectomy in the rat. Anat. Rec. Suppl. 70, 51.

Bradbury, J. T., Brown, W. E. \& Gray, L. A. (1950) Maintenance of the corpus luteum and physiologic actions of progesterone. Recent Prog. Horm. Res. 5, 151.

BRuce, H. M. (1967) Effects of olfactory stimuli on reproduction in mammals. In: The Effects of External Stimuli on Reproduction, p. 29. Eds. G. E. W. Wolstenholme and M. O'Connor. Giba Foundation Study Group No. 26. Churchill, London.

Cerruti, R. A. \& Lyons, W. R. (1960) Mammogenic activities of the mid-gestational mouse placenta. Endocrinology, 67, 884 .

Choudary, J. B. \& Greenwald, G. S. (1969) Ovarian activity in the intact or hypophysectomized pregnant mouse. Anat. Rec. 163, 359.

DEANESLY, R. (1967) Normal growth and persistence of corpora lutea of both ovaries in the unilaterally pregnant guinea-pig. 7. Reprod. Fert. 14, 519.

Deanesly, R. \& Newton, W. H. (1940) The influence of the placenta on the corpus luteum of pregnancy in the mouse. F. Endocr. 2, 317.

Dewar, A. D. (1957a) The endocrine control of the extra-uterine weight gain of pregnant mice. $\mathcal{F}$. Endocr. 15, 230.

DEwAr, A. D. (1957b) Body weight changes in the mouse during the oestrous cycle and pseudopregnancy. 7. Endocr. 15, 230.

DEwaR, A. D. (1959) Observations on pseudopregnancy in the mouse. 7. Endocr. 18, 186.

Duby, R. T., McDaniel, J. W., Spilman, C. H. \& Black, D. L. (1969) Utero-ovarian relationships in the golden hamster. III. Influence of uterine transplants and extracts on ovarian function following hysterectomy. Acta endocr., Copenh. 60, 611 .

Ershoff, B. H. \& Deuel, H. J. (1943) Prolongation of pseudopregnancy by induction of deciduomata in the rat. Proc. Soc. exp. Biol. Med. 54, 167.

Forbes, T. R. \& Hooker, C. W. (1957) Plasma levels of progestin during pregnancy in the mouse. Endocrinology, 61, 281.

Gardner, W. U. \& Allen, E. (1942) Effects of hypophysectomy at mid-pregnancy in the mouse. Anat. Rec. 83, 75.

HALL, K. (1957) The effect of relaxin extracts, progesterone and oestradiol on maintenance of pregnancy, parturition and rearing of young after ovariectomy in mice. F. Endocr. 15, 108.

Hechter, O., Fraenkel, M., Lev, M. \& Soskin, S. (1940) Influence of the uterus on the corpus luteum. Endocrinology, 26, 680.

Kamell, S. A. \& AtKinson, W. B. (1948) Absence of prolongation of pseudopregnancy by induction of deciduomata in the mouse. Proc. Soc. exp. Biol. Med. 67, 415.

KIRBY, D. R. S. (1965) Endocrinological effects of experimentally induced extra-uterine pregnancies in virgin mice. 7. Reprod. Fert. 10, 403.

KLEıN, M. (1935) Recherches sur le rôle du placenta dans l'arrêt des manifestations du cycle au cours de la grossesse. Archs Anat. microsc. Morph. exp. 31, 397.

Ladman, A. J. \& Runner, M. N. (1953) Demonstration of storage and release of gonadotrophin by the anterior pituitary of the mouse during gestation. Endocrinology, 53, 367.

Long, J. A. \& Evans, H. M. (1922) The oestrous cycle in the rat and its associated phenomena. Mem. Univ. Calif. 6, 1.

Mcl aren, A. (1970) The fate of very small litters produced by egg transfer in mice. 7. Endocr. $47,87$.

Melampy, R. M. \& Anderson, L. L. (1968) Role of the uterus in corpus luteum function. F. Anim. Sci. 27, Suppl. 1, 77 .

Mirskaia, L. (1930) On the presence of a kyogenic substance in the mouse placenta. Proc. R. Soc. Edinb. $50,104$.

Mook, R. M. \& Rowson, L. E. A. (1966) Local maintenance of the corpus luteum in sheep with embryos transferred to various isolated portions of the uterus. J. Reprod. Fert. 12, 539.

Murphy, D. P. (1934) The weight of rat ovaries after hysterectomy. Anat. Rec. 60, 77.

Nalbandov, A. V. (1961) Comparative physiology and endocrinology of domestic animals. Recent Prog. Horm. Res. 17, 119.

Newton, W. H. (1935) "Pseudo-parturition" in the mouse and the relation of the placenta to postpartum oestrus. J. Physiol., Lond. 84, 196.

Newton, W. H. (1949) Some aspects of the physiology of pregnancy. In: Recent Advances in Physiology, Ed. W. H. Newton. Churchill, London. 
Newton, W. H. \& Beck, N. (1939) Placental activity in the mouse in the absence of the pituitary gland. F. Endocr. 1, 65.

Palmer, A. \& Fulton, L. (1941) Decreased ovarian response to chorionic gonadotrophin following hysterectomy in the mouse. Nature, Lond. 148, 596.

Parkes, A. S. (1928) The role of the corpus luteum in the maintenance of pregnancy. F. Physiol, Lond. 65,341 .

PERRY, J. S. \& Rowlands, I. W. (1961) Effect of hysterectomy on the ovarian cycle of the rat. F. Reprod. Fert. 2, 332.

Robson, J. M. (1938a) Quantitative data on the inhibition of oestrus by testosterone, progesterone and certain other compounds. F. Physiol., Lond. 92, 371.

Rosson, J. M. (1938b) Mechanism of oestrus inhibition in the mouse during pregnancy. Q. $f l$ exp. Physiol. 28, 195.

RoтнснILD, 1. (1965) Interrelations between progesterone and the ovary, pituitary and central nervous system in the control of ovulation and regulation of progesterone secretion. Vitams Horm. 23, 209.

Selye, H., Collip, J. B. \& Thomson, D. L. (1933) Effect of hypophysectomy upon pregnancy and lactation in mice. Proc. Soc. exp. Biol. Med. 31, 82.

Silbiger, M. \& Rothchild, I. (1963) The influence of the uterus on the corpus luteum-pituitary relationship in the rat. Acta endocr., Copenh. 43, 521.

Slonaker, J. R. (1929) Pseudopregnancy in the albino rat. Am. 7. Physiol. 89, 406.

Steinetz, B. G., BeAch, V. L. \& Kroc, R. L. (1956) The influence of progesterone and relaxin on the response of the nineteen-day pregnant mouse to oxytocin. Anat. Rec. 124, 365.

Strauss, J. F. \& LindNER, H. R. (1969) Maintenance of luteal function during unilateral pregnancy in the rat. F. Reprod. Fert. 18, 129.

Tutze, K. (1952) Der weibliche Zyklus und seine Störungen. In: Biologie und Pathologie des Weibes, Vol. 2, p. 49. Eds. L. Seitz and A. I. Amreich. Urban und Schararzenberg, Vienna.

WAYNForth, H. B. (1971) Changes in the volume of rat corpus luteum during pregnancy and after surgical interference with the uterus and placenta. Acta endocr., Copenh. 66, 296.

Westman, A. (1929) Untersuchungen über die Ovarialfunktion nach Uterusextirpation. Zentbl. Gynäk. 53, 2578.

Zeilmaker, G. H. (1968) Luteotrophic activity of the ectopic mouse trophoblast. F. Endocr. 41, 455. 